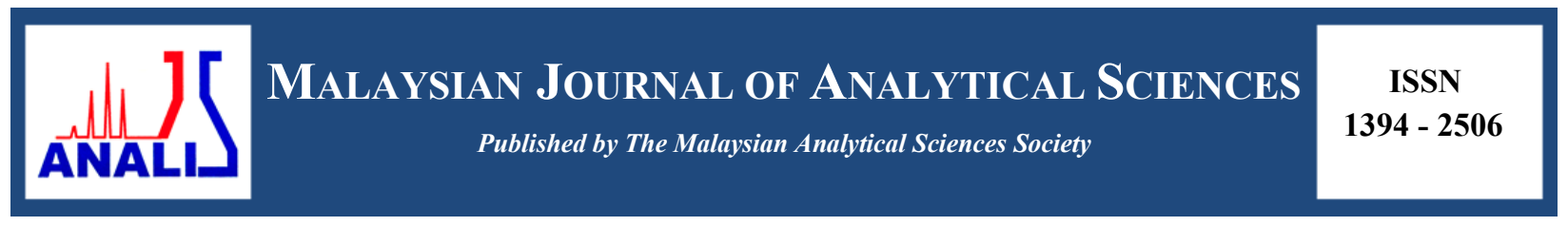

\title{
FREE FATTY ACIDS SEPARATION FROM MALAYSIAN HIGH FREE FATTY ACID CRUDE PALM OIL USING MOLECULAR DISTILLATION
}

\section{(Pemisahan Asid Lemak Bebas daripada Minyak Sawit Mentah Berasid Lemak Bebas Tinggi Melalui Penyulingan Molekul)}

\author{
Murad Awadh Bahadi ${ }^{1,2}$, Abd-Wali Japir², Nadia Salih², Jumat Salimon ${ }^{2} *$ \\ ${ }^{1}$ Faculty of Education and Sciences, \\ Hadhramout University, Yemen \\ ${ }^{2}$ School of Chemical Sciences and Food Technology, Faculty of Science and Technology, \\ Universiti Kebangsaan Malaysia, 43600 UKM Bangi, Selangor, Malaysia \\ *Corresponding author: jumat@ukm.edu.my
}

Received: 14 February 2016; Accepted: 23 May 2016

\begin{abstract}
Molecular distillation is industrially useful in the purification of highly oxidative oils and fats, and their derivatives. Free Fatty Acids (FFAs) were isolated from high free fatty acid crude palm oil (HFFA-CPO) using molecular distillation. The isolation conditions were set-up with feeder flow rate of $2.3 \mathrm{~g} / \mathrm{min}$, wipers speed of $350 \mathrm{rpm}$, evaporator temperature ranging from $150{ }^{\circ} \mathrm{C}$ to $265{ }^{\circ} \mathrm{C}$ and pressure at 10 torr respectively. The results showed that the yield of crude palm oil after separation $\left(\mathrm{CPO}_{\mathrm{AS}}\right)$ was $88 \%(\mathrm{wt} / \mathrm{wt})$. The physicochemical properties of $\mathrm{CPO}_{\mathrm{AS}}$ showed a distinct difference in acid value, FFA content, iodine value and hydroxyl value compared to that of HFFA-CPO and it is more favourable for food product usage. The results showed that $\mathrm{CPO}_{\mathrm{AS}}$ has lower acid value (reduced from $21.3 \pm 0.1$ to $2.1 \pm 0.01 \mathrm{mg} \mathrm{NaOH} / \mathrm{g}$ ), increased iodine value from $50.6 \pm 0.2$ to 53.5 $\pm 0.2 \mathrm{mg} \mathrm{KOH} / \mathrm{g}$, reduced hydroxyl value from $43.4 \pm 0.2$ to $25.5 \pm 0.1 \mathrm{mg} \mathrm{KOH} / \mathrm{g}$ and lower FFA content from $9.4 \pm 0.1 \%$ to $0.9 \pm 0.1 \%$ in $\mathrm{CPO}_{\mathrm{AS}}$ respectively. The work has proven that molecular distillation is an effective method for the separation of FFA from high free fatty acid crude palm oil.
\end{abstract}

Keywords: free fatty acid, crude palm oil, molecular distillation

Penyulingan molekul adalah bermanfaat untuk industri bagi penulenan minyak dan lemak yang telah teroksida, serta bahanbahan terbitannya. Asid lemak bebas (FFA) telah dipisahkan daripada minyak sawit mentah berasid lemak bebas tinggi (HFFA$\mathrm{CPO}$ ) menggunakan penyulingan molekul. Keadaan pemisahan telah ditetapkan masing-masing dengan kadar alir suapan pada $2.3 \mathrm{~g} / \mathrm{min}$, laju pengelap $350 \mathrm{rpm}$, suhu penyejat daripada $150{ }^{\circ} \mathrm{C}$ hingga $265{ }^{\circ} \mathrm{C}$ dan tekanan pada 10 torr. Hasil kajian menunjukkan peratusan hasil minyak sawit mentah selepas proses pemisahan $\left(\mathrm{CPO}_{\mathrm{AS}}\right)$ adalah $88 \%$ (wt/wt). Sifat fiziko-kimia $\mathrm{CPO}_{\mathrm{AS}}$ menunjukan beberapa perbezaan dalam nilai asid, kandungan FFA, nilai iodin dan nilai hidroksil berbanding dengan HFFA-CPO. Hasil kajian membuktikan $\mathrm{CPO}_{\mathrm{AS}}$ mempunyai nilai asid yang lebih rendah (menurun daripada $21.3 \pm 0.1 \mathrm{kepada}$ $2.1 \pm 0.01 \mathrm{mg} \mathrm{NaOH} / \mathrm{g}$ ), nilai iodin meningkat daripada $50.6 \pm 0.2 \mathrm{kepada} 53.5 \pm 0.2 \mathrm{mg} \mathrm{KOH} / \mathrm{g}$, nilai hidroksil menurun daripada $43.4 \pm 0.2 \mathrm{kepada} 25.5 \pm 0.1 \mathrm{mg} \mathrm{KOH} / \mathrm{g}$ dan kandungan FFA menurun daripada $9.4 \pm 0.1 \%$ bagi HFFA-CPO kepada $0.9 \pm 0.1 \%$ bagi $\mathrm{CPO}_{\mathrm{AS}}$. dan menjadikannya lebih sesuai untuk digunakan dalam kegunaan makanan. Kajian ini telah membuktikan bahawa penyulingan molekul adalah suatu kaedah efektif bagi pemisahan FFA daripada minyak sawit mentah berasid lemak tinggi.

Kata kunci: asid lemak bebas, minyak sawit mentah, penyulingan molekul 


\section{Bahadi et al: FREE FATTY ACIDS SEPARATION FROM MALAYSIAN HIGH FREE FATTY ACID CRUDE PALM OIL USING MOLECULAR DISTILLATION}

\section{Introduction}

South East Asia and Equatorial Africa are considered the best locations where palm oil is widely grown and produced. In fact, there are mainly two types of oil which can be obtained from palm oil. The first part is known as crude palm oil from the flesh of the fruit (mesocarp), and the second part is palm kernel oil from the seed or kernel. Unripe fruit contains very little oil, but the mesocarp of ripe fruits has an oil content of $(70-75 \%)$ of its total weight. In Malaysia, production of palm oil is considered as one of the highest among other producing countries, due to the suitable climate and proper management $[1,2]$. Crude palm oil (CPO) mainly consists of glycerides and small quantities of non-glyceride components. The non-glyceride components include free fatty acids (FFAs), trace metals, moisture, impurities and minor components [3]. The fatty acid composition of crude palm oil is mainly palmitic (44\%), stearic (4\%), oleic (40.6\%) and linoleic (9.8\%) [4].

According to literatures, Prasanth et al. [5] and Azlan et al. [6] reported, the Malaysian crude palm oil comprises more than $(80 \%)$ triacylglyceride, $(3-8 \%)$ diacylglyceride, less than $(3 \%)$ monoacylglyceride and $(3-4 \%)$ free fatty acids and approximately $(1 \%)$ of minor components which include carotenoids, vitamin $\mathrm{E}$ (tocopherols and tocotrienols), sterols, phospholipids, glycolipids, and terpenic and aliphatic hydrocarbons. Based on the standards by Malaysian Palm Oil Board (MPOB), the basic quality specifications of CPO are maximum $5 \%$ FFA and $0.25 \%$ of moisture content and impurity respectively [7]. Meanwhile, the Palm Oil Refiners Association of Malaysia (PORAM) specifies lower than $0.1 \%$ FFA content in palm oil [8].

The high level of FFAs in CPO indicates its lower ability due to the enzymeic and microbial lipase reactions of palm fruit, as well as the storage of CPO under bad conditions such as high temperature and high moisture which can affect the quality of oil $[9,10]$. The most commonly used methods for FFA separation are molecular distillation, chemical esterification, supercritical extraction, and organic solvent nanofiltration [11, 12]. Chemical esterification with or without catalyst involves separation of FFA from the crude palm oil at high temperature and inert medium with free hydroxyl groups remain in the oil. Supardan and Satriana [12] effectively reduced FFA content from 33.3 $\%$ to $1 \%$ through esterification with methanol using sulphuric acid as catalyst at $1 \%(\mathrm{wt} / \mathrm{wt})$. Although high rate of FFA can be removed using chemical esterification, high temperature during distillation would increase the production cost. In another study, Shah and Venkatesan [13] achieved selectively free fatty acids separation from vegetable oil at ambient temperature using $75 \%$ aqueous and $80 \%$ isopropyl alcohol as the extraction solvent. The key factor which has contributed to such effective separation is the presence of water in the aqueous isopropyl. As the free fatty acids were transferred into the aqueous isopropyl layer, a progressive decoupling effect was exerted on the alcohol and oil layers and consequently formed immiscible phases.

The molecular distillation process is a useful mechanism to separate and purify high molecular weight materials, as well as compounds that are thermally sensitive such as free fatty acids and vitamins. Furthermore, this technique offers a major advantage that it avoids problems with toxicity among others that use solvents as the separating agent. Molecular distillation processes, enable maximum removal of free fatty acids by manipulating the feed flow rate and temperature of distillation for the extraction of minor components from palm fatty acid distillates. The removal capacity is associated to the yield, purity, and rate of evaporation in terms of concentrations, distribution coefficients, and relative volatilities $[14,15]$. In previous study, molecular distillation has been employed to reduce FFAs from soybean oil by varying the operating conditions. High separation was achieved in the distillate with $81.37 \%$ FFA, performed under $140{ }^{\circ} \mathrm{C}$ evaporator temperature and $1.87 \mathrm{~g} / \mathrm{min}$ feed flow rate [15].

The FFA content is an important specification that influences the palm oil quality within the production, storage and marketing stages. The objective of this research work was to extract the FFAs from the HFFA-CPO and to determine the physicochemical properties.

\section{Sample collection}

\section{Materials and Methods}

Malaysian high free fatty acid crude palm oil (HFFA-CPO) was obtained from a local refinery, Sime Darby, Selangor Malaysia. 


\section{Chemicals and reagent}

Sodium hydroxide, potassium iodide, Wijs solution, n-hexane, sodium thiosulphate, potassium hydroxide, hydrochloric Acid, acetic anhydride, pyridine and ethyl alcohol were purchased from Sigma-Aldrich.

\section{Free fatty acid separation}

Free fatty acid separation from high free fatty acid crude palm oil was carried out using molecular distillation apparatus (Incon ILC-04 SPD, USA). HFFA-CPO of $100 \mathrm{~g}$ was added into a feed tank. The conditions of distillation were as follows: 10 torr (pressure), $60{ }^{\circ} \mathrm{C}$ (condenser temperature), $150{ }^{\circ} \mathrm{C}-270{ }^{\circ} \mathrm{C}$ (evaporator temperature), $2.3 \mathrm{~g} / \mathrm{min}$ feed flow rate and 350 wiper basket speed. After distillation, the distillate and retentate products were collected, weighed and analysed.

\section{Chemical characteristic analysis:}

Acid value $(A V)$ \& FFA \%

Acid value of oil was determined according to AOCS (1989) standard methods Cd 3a-63[16]. FFA \% and acid value in $\mathrm{CPO}$ as palmitic acid was calculated using the following equations 1 and 2 below:

$$
\% \text { FFA as Palmitic acid }=\frac{25.6 \times \mathrm{N} \times V}{W}
$$

where the value of 25.6 is the formula for FFA determination is equivalence factors for palmitic acid; the predominant fatty acid in palm oil. $\mathrm{N}$ is normality of $\mathrm{NaOH}, \mathrm{V}$ is volume of $\mathrm{NaOH}$ solution used in $\mathrm{mL}$ and $\mathrm{W}$ is weight of sample.

$$
\text { Acid value }=\% \text { FFA as palmitic acid } \times 2.19
$$

where the value of 2.19 is the conversion factor for palmitic acid.

\section{Iodine value (IV)}

The iodine value was calculated as recommended by the (AOCS 1989) standard methods Cd 1-25 [16] as given in equation 3 below:

$$
\mathrm{I} . \mathrm{V}=\frac{12.69 \times \mathrm{N}(\mathrm{Vb}-\mathrm{Vs})}{W}
$$

where $\mathrm{N}$ is the normality of the $\mathrm{Na}_{2} \mathrm{~S}_{2} \mathrm{O}_{3}$ solution, $\mathrm{Vb}$ is the volume $(\mathrm{mL})$ of $\mathrm{Na}_{2} \mathrm{~S}_{2} \mathrm{O}_{3}$ solution used for the blank test, $\mathrm{Vs}$ is the volume $(\mathrm{mL})$ of $\mathrm{Na}_{2} \mathrm{~S}_{2} \mathrm{O}_{3}$ solution used for the determination of the sample, $\mathrm{W}$ is the weight in grams of the sample test portion. The value of 12.69 are used to transfer equivalent thiosulphate to $\mathrm{g}$ (iodine). The molecular mass unit or relative molecular unit of iodine is 126.9.

\section{Saponification value and unsaponifiable matter}

Saponification value and unsaponifiable matter of oil were determined by adopting the methods by Salimon et al. [17].

\section{Hydroxyl value}

Hydroxyl value was determined according to AOCS standard methods Cd 13-60 [16].

\section{Physical characteristic analysis \\ Colour}

The oil colour was determined using a Lovibond tintometer Model F/10508, according to the PORIM test method [18]. The frozen oil samples were melted by placing them in an oven at a temperature of $60{ }^{\circ} \mathrm{C}$. The liquefied samples were placed into an inch cell up to three quarters full, and the colour was determined at $28^{\circ} \mathrm{C}$ by achieving the best possible match with the standard colour slides of red and yellow indices. 


\section{Bahadi et al: FREE FATTY ACIDS SEPARATION FROM MALAYSIAN HIGH FREE FATTY ACID CRUDE PALM OIL USING MOLECULAR DISTILLATION}

\section{Viscosity}

The viscosity of the HFFA-CPO and $\mathrm{CPO}_{\mathrm{AS}}$ was determined using a Brook field model RV DV-I+ (U.S.A) Spindle of SO5. The viscosity was read in Pascal second (Pa.s) directly from the viscometer, which was maintained at $1 \mathrm{~min}$ and $100 \mathrm{rpm}$ at room temperature.

\section{Moisture Content}

The moisture content of HFFA-CPO and $\mathrm{CPO}_{\mathrm{AS}}$ was determined by using a Moisture Analyzer model AND MX50. Approximately $5 \mathrm{~g}$ of $\mathrm{CPO}$ was weighed into a moisture dish, and dried in the moisture analyser for 30 minutes at $101{ }^{\circ} \mathrm{C}$.

\section{Refractive Index}

The refractive index of HFFA-CPO and $\mathrm{CPO}_{\mathrm{AS}}$ was determined according to AOCS standard methods Cc 7-25, [16] using a refractometer at $26.5^{\circ} \mathrm{C}$.

\section{Specific gravity}

The density of HFFA-CPO and $\mathrm{CPO}_{\mathrm{AS}}$ was obtained using a delicate balance. An amount $1 \mathrm{~mL}$ of oil was placed on a balance, and its weight was recorded at room temperature. Later, the specific gravity was determined according to The Lund relationship [19].

\section{Free fatty acid and fatty acid composition}

The fatty acid composition (FAC) of HFFA-CPO and $\mathrm{CPO}_{\mathrm{AS}}$ were determined using a Gas Chromatography (Shimadzu GC-17A) equipped with a capillary column BPX $70(30 \mathrm{~m} \times 0.25 \mathrm{~mm} \times 0.25 \mu \mathrm{m})$ and an FID detector. The column temperature was programmed at $120{ }^{\circ} \mathrm{C}$, with an increment of $3{ }^{\circ} \mathrm{C}$ per minute up to $245^{\circ} \mathrm{C}$, whereas the injector and detector temperature were set at $260^{\circ} \mathrm{C}$ and $280{ }^{\circ} \mathrm{C}$ respectively. High purity helium gas $(99.99 \%)$ was used as the carrier gas with a flow rate of $0.3 \mathrm{~mL} / \mathrm{min}$. Fatty acid methyl ester (FAME) was prepared with basecatalysed trans esterification according to Salimon et al [17], and using acid-catalysed transesterification proposed by Ichihara et al. [20]. Peaks were identified by comparing with the retention times of the authentic standards.

\section{Analysis of TAG in crude palm oil}

Chromatography separation was performed using High performance liquid chromatography (HPLC), model 1525 equipped with refractive index detector and Spherisorb C18 $(5 \mu \mathrm{m} ; 250 \times 4.6 \mathrm{~mm})$ column. HPLC was employed to analyse the triacylglyceride, diacylglyceride, monoacylglyceride and free fatty acid. The parameters of HPLC were carried out according to Cunha et al. [21]. The eluent used was a gradient of acetone (A) and acetonitrile (B). Elution was performed with a solvent flow rate of $0.4 \mathrm{~mL} / \mathrm{min}$ with a linear gradient as follows: 0 min $30 \% \mathrm{~B}, 20$ $\min 25 \% \mathrm{~B}, 35 \mathrm{~min} 20 \% \mathrm{~B}$ and maintained for $20 \mathrm{~min}$ before returning to the initial conditions within $3 \mathrm{~min}$. The effluent was monitored with an ELSD detector with the following settings: evaporator temperature of $40{ }^{\circ} \mathrm{C}$, air pressure of 3.5 bar and photomultiplier sensitivity of 6 . The samples were prepared by dissolving $0.15 \mathrm{~g}$ in $5 \mathrm{~mL}$ mixture of acetone: acetonitrile (63.5:36.5) prior to injection into the HPLC.

\section{Fourier transform infrared spectroscopy analysis of crude palm oil}

Fourier Transform Infrared Spectroscopy (FTIR) analysis was carried out according to Salimon et al. method [22]. FTIR spectrum was recorded with Perkin Elmer Spectrum GX spectrophotometer in the range of 700-4000 $\mathrm{cm}^{-1}$. FTIR was used to measure functional groups of HFFA-CPO and $\mathrm{CPO}_{\mathrm{AS}}$. A very thin film of HFFA-CPO and $\mathrm{CPO}_{\mathrm{AS}}$ were individually covered on $\mathrm{NaCl}$ cells $(25 \mathrm{~mm}$ i.d $\times 4 \mathrm{~mm}$ thickness $)$ and were used for analysis.

\section{Free fatty acid separation}

\section{Results and Discussion}

Molecular distillation separates free fatty acids from HFFA-CPO at varying evaporator temperature depending to the boiling points of the fatty acids. It usually operates with a low feeder flow rate of $2.3 \mathrm{~g} / \mathrm{min}$ and wiper speed of $350 \mathrm{rpm}$. As the evaporator temperature reached the boiling points of the free fatty acid, the distillate flow rate will increase with the feed flow rate and the highest processing capacity of the unit should be achieved. However, heat transfer limitation between the oils and evaporator will maintain a steady distillate flow rate. At that time when the 
feed flow rate has been increased, the material volume inside the evaporator is already high. Therefore, the heat transfer efficiency between the material and the evaporator is reduced due to poor contact with the evaporator walls, thereby, declines the separation ratio [15].

When the HFFA-CPO was subjected to the molecular distillation, it was split in two fractions, the residue and distillate. The residue comprises low PFAD of crude palm oil $\left(\mathrm{CPO}_{\mathrm{AS}}\right)$ and the recovered FFA in the distillate (PFAD). The percentage yield of DFA and $\mathrm{CPO}_{\mathrm{AS}}$ is shown in Table 1. It shows in the distillate, the DFA yield is $12 \%$ with $97.3 \pm 0.1 \%$ acid value which suggest that the distillate contains relatively high percentage of FFA. According to MPOB standards [7], the specified FFA value of a CPO should be lower than $5 \%$ to avoid any defects on the quality of the oil. In this study, the residue has a lower percentage of FFA in $\mathrm{CPO}_{\mathrm{AS}}(0.9 \pm 0.1 \%)$. Based on these results, the $\mathrm{CPO}_{\mathrm{AS}}$ in the residue exhibits the property of edible oil, and the FFA recovered in the distillate can be utilized in future industrial applications.

Table1. Yield of DFA and $\mathrm{CPO}_{\mathrm{AS}}$ after molecular distillation of $100 \mathrm{~g}$ HFFA-CPO

\begin{tabular}{lcc}
\hline & Distillate (PFAD) & Residue $\left(\mathbf{C P O}_{\text {AS }}\right)$ \\
\hline Yield (\%) & 12 & 88 \\
FFA (\%) & $97.3 \pm 0.1$ & $0.9 \pm 0.1$ \\
\hline
\end{tabular}

\section{FTIR analysis of HFFA-CPO and $\mathrm{CPO}_{\mathrm{AS}}$}

Verification of the isolated FFA from HFFA-CPO was carried out using FTIR spectroscopy. The characteristic of main functional groups in HFFA-CPO and $\mathrm{CPO}_{\mathrm{AS}}$ is given in Table 2.

Table 2. The functional groups of HFFA-CPO and $\mathrm{CPO}_{\mathrm{AS}}$ in terms of main wavenumber in the FTIR

\begin{tabular}{lll}
\hline \multirow{2}{*}{ Functional group } & \multicolumn{2}{l}{ Wavenumber $\left.\mathbf{( c m}^{-1}\right)$} \\
\cline { 2 - 3 } & HFFA-CPO & $\mathbf{C P O}_{\mathbf{A S}}$ \\
\hline OH stretching (FA) & 3473 & - \\
C = C bending vibration (aliphatic) & 3006 & 3005 \\
C-H stretching vibration (aliphatic) & 2921,2853 & 2923,2853 \\
C = O stretching vibration (ester) & 1744 & 1746 \\
C = O stretching vibration (carboxylic acid) & 1714 & - \\
C-H scissoring and bending for methylene & 1465 & 1464 \\
=C-H (cis) Unsaturated & 1417 & 1417 \\
-CH3 sym deformation & 1377 & 1377 \\
-C-O-Stretching vibration(ester) & $1238-1165$ & $1237-1164$ \\
C-H group vibration (aliphatic) & 722 & 722 \\
\hline
\end{tabular}

Notes:HFFA-CPO high free fatty acid crude palm oil, $\mathrm{CPO}_{\mathrm{AS}}$ crude palm oil after separation

Figure 1 shows the FTIR spectrum of HFFA-CPO where the peaks of $\mathrm{C}=\mathrm{O}$ for carboxylic acid and ester were clearly seen at $1714 \mathrm{~cm}^{-1}$ and $1744 \mathrm{~cm}^{-1}$, respectively. However, the peak of $\mathrm{C}=\mathrm{O}$ of carboxylic acid disappeared after separation (Figure 1) which proven the effectiveness of the FFA separation process. The $\mathrm{C}=\mathrm{O}$ (ester) peak in $\mathrm{CPO}_{\mathrm{AS}}$ appeared at $1746 \mathrm{~cm}^{-1}$ and the $\mathrm{OH}$ stretching also disappeared after molecular distillation as shown in Figure 1. 


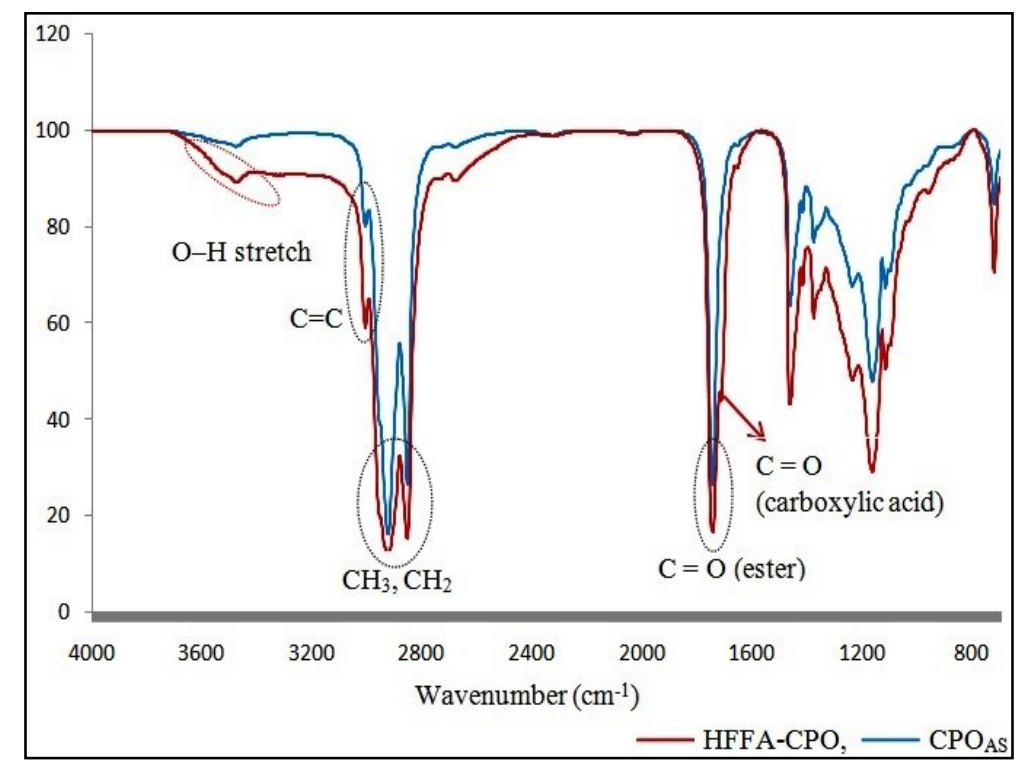

Figure 1. FTIR spectrum of HFFA-CPO and $\mathrm{CPO}_{\mathrm{AS}}$

\section{Physicochemical properties of $\mathrm{HFFA}-\mathrm{CPO}$ and $\mathrm{CPO}_{\mathrm{AS}}$}

Table 3 presents the physicochemical properties of HFFA-CPO and $\mathrm{CPO}_{\mathrm{AS}}$. These properties are different in terms of the acid value, iodine value and hydroxyl value. They have similar physical properties despite the slight differences in their specific parameter values. The result shows that the average value of FFA for HFFA-CPO is high $(9.4 \pm 0.1 \%)$. FFA is one of the most important quality parameters in the palm oil industry as it indicates the level of deterioration of the oil. The FFA limit in Malaysian palm oil mills is $5 \%$ [23], which clearly remarks that the FFA of $\mathrm{CPO}_{\mathrm{AS}}(0.9 \pm 0.01 \%)$ is within standard requirement and therefore, is edible. The iodine values of the HFFA-CPO and $\mathrm{CPO}_{\mathrm{AS}}$ were $50.6 \pm 0.2 \mathrm{mg} / \mathrm{g}$ and $53.5 \pm 0.2 \mathrm{mg} / \mathrm{g}$ respectively. This was due to the high content of unsaturated fatty acids in $\mathrm{CPO}_{\mathrm{AS}}$. This value is compatible with a typical palm oil [24]. The colour of HFFA-CPO and $\mathrm{CPO}_{\mathrm{AS}}$ was 50 red and 40 yellow at room-temperature. In addition to that, their refractive value at $28{ }^{\circ} \mathrm{C}$ is equal to 1.4669 . The $\mathrm{CPO}_{\mathrm{AS}}$ shows high viscosity at room temperature (0.060 Pa.s) compared to HFFA-CPO (0.052 Pa.s). The results of $\mathrm{CPO}_{\mathrm{AS}}$, shown in Table 3, are similar to the physicochemical properties Malaysian crude palm oil standard $\left(\mathrm{CPO}_{\mathrm{MS}}\right)$. Thus, the separation process was optimally conducted and this makes it possible for the product to be used for food industry.

\section{Fatty acid composition}

The fatty acid composition and FFA of HFFA-CPO and $\mathrm{CPO}_{\mathrm{AS}}$ are summarized in Table 4. By comparison, it was proven from this work that the FFA compositions are within the standard permitted by Malaysian palm oil standard $\left(\mathrm{CPO}_{\mathrm{MS}}\right)$ [26]. The results exhibit only a slight difference between the fatty acids composition of HFFA-CPO and $\mathrm{CPO}_{\mathrm{AS}}$ from the base-catalysed reaction, and the values are within the standard requirements by Malaysian palm oil. Table 2 have shown palmitic acid and stearic acid as the major saturated fatty acids in HFFA-CPO. The values before and after separation are $(45.7 \%)$ and $(43.9 \%)$ for palmitic acid; $(4.3 \%)$ and $(4.2 \%)$ for stearic acid respectively. The main unsaturated fatty acids in HFFA-CPO were oleic acid and linoleic acid, with values of (39.5 $\%)$ and $(9.4 \%)$ respectively, meanwhile in $\mathrm{CPO}_{\mathrm{AS}}$ the values obtained are (39.8\%) and (10.7\%) respectively.

Table 4 shows that the compositions of fatty acids for $\mathrm{CPO}_{\mathrm{AS}}$ are within the Malaysian palm oil standard. Furthermore, the composition of FFA in HFFA-CPO and $\mathrm{CPO}_{\mathrm{AS}}$ from the transesterification with acid catalyst is close to each other, with only minor difference with base-catalysed. FFA of HFFA-CPO and $\mathrm{CPO}_{\mathrm{AS}}$ Palmitic acid $(44 \%)$ and stearic acid (4\%) were the major components of HFFA-CPO and $\mathrm{CPO}_{\mathrm{AS}}$ obtained from the acid- 
catalysed transesterification comprises of (44.2\%) palmitic acid and (4\%) stearic acid. Oleic acid and linoleic acid as the main components of unsaturated fatty acids in HFFA-CPO were recorded as $(39.8 \%)$ and $(10.7 \%)$ respectively. These values were increased slightly to $(39.1 \%)$ and $(11.1 \%)$ for $\mathrm{CPO}_{\mathrm{AS}}$. In addition, the composition of fatty acids for Distillate of free fatty acid (PFAD) obtained from the acid-catalysed transesterification comprises of lauric acid (0.2\%), myristic acid (0.7\%), palmitic acid (57.4\%), stearic acid (4.8\%), oleic acid (34.6\%) and linoleic acid $(2.3 \%)$.

Table 3. Physicochemical properties of HFFA-CPO and $\mathrm{CPO}_{\mathrm{AS}}$

\begin{tabular}{lrrr}
\hline Parameter & HFFA-CPO & \multicolumn{1}{c}{ CPO $_{\text {AS }}$} & \multicolumn{1}{c}{ CPO $_{\text {MS }}{ }^{\text {a }}$} \\
\hline Iodine value $(\mathrm{mg} / \mathrm{g})$ & $50.6 \pm 0.2$ & $53.5 \pm 0.2$ & $50.4-53.7$ \\
FFA $(\%)$ & $9.4 \pm 0.1$ & $0.9 \pm 0.1$ & $<5 \%$ \\
Acid value $(\mathrm{mg} / \mathrm{g})$ & $21.3 \pm 0.1$ & $2.1 \pm 0.01$ & $<5 \%$ \\
Saponification value $(\mathrm{mg} / \mathrm{g})$ & $203.1 \pm 0.1$ & $200.8 \pm 0.1$ & $194-205$ \\
Unsaponifiable matter $(\%)$ & $0.7 \pm 0.1$ & $0.39 \pm 0.2$ & $0.19-0.44$ \\
Average molecular weight $(\mathrm{g} / \mathrm{mol})$ & 828.7 & 837.4 & - \\
Hydroxyl value $(\mathrm{mg} / \mathrm{g})$ & $43.4 \pm 0.2$ & $25.5 \pm 0.1$ & - \\
Specific gravity $(\mathrm{g} / \mathrm{ml})$ & 0.878 & 0.841 & $0.8889-0.8896$ \\
Refractive index at $28^{\circ} \mathrm{C}$ & 1.4669 & 1.4669 & $1.4521-1.4541$ \\
Moisture content $(\%)$ & 0.6 & 0.2 & $<0.25 \%$ \\
Viscosity $\left(28^{\circ} \mathrm{C}\right)(\mathrm{Pa} \cdot \mathrm{s})$ & 0.052 & 0.060 & - \\
Colour at $28^{\circ} \mathrm{C}$ & $50 \mathrm{R}-40 \mathrm{Y}$ & $50 \mathrm{R}-40 \mathrm{Y}$ & - \\
\hline
\end{tabular}

a: [22], HFFA-CPO: high free fatty acid crude palm oil, $\mathrm{CPO}_{\mathrm{AS}}$ : Crude palm oil after separation free fatty acid, $\mathrm{CPO}_{\mathrm{MS}}$ : Malaysian crude palm oil standard.

Table 4. FA composition in HFFA-CPO and $\mathrm{CPO}_{\mathrm{AS}}$ with base-catalysed transesterification (\%) and FFA composition of HFFA-CPO, $\mathrm{CPO}_{\mathrm{AS}}$ and PFAD with acid-catalysed transesterification

\begin{tabular}{lcccccc}
\hline $\begin{array}{l}\text { Fatty acid } \\
\text { composotion }\end{array}$ & \multicolumn{3}{c}{ Base-catalysed } & \multicolumn{4}{c}{ Acid-catalysed } \\
\cline { 2 - 7 } & $\begin{array}{c}\text { HFFA-CPO } \\
\text { \% }\end{array}$ & $\begin{array}{c}\mathbf{C P O}_{\text {AS }} \\
\text { \% }\end{array}$ & CPO $_{\text {MS }}{ }^{\text {a }}$ & $\begin{array}{c}\text { HFFA-CPO } \\
\text { \% }\end{array}$ & $\begin{array}{c}\mathbf{C P O}_{\text {AS }} \\
\text { \% }\end{array}$ & $\begin{array}{c}\text { PFAD } \\
\text { \% }\end{array}$ \\
\hline C12:0 & 0.2 & 0.3 & 0.2 & 0.4 & 0.5 & 0.2 \\
C14:0 & 0.9 & 1.1 & 1.1 & 1.1 & 1.1 & 0.7 \\
C16:0 & 45.7 & 43.9 & 43.5 & 44 & 44.2 & 57.4 \\
C18:0 & 4.3 & 4.2 & 4.3 & 4. & 4 & 4.8 \\
C18:1 & 39.5 & 39.8 & 39.8 & 39.8 & 39.1 & 34.6 \\
C18:2 & 9.4 & 10.7 & 10.2 & 10.7 & 11.1 & 2.3 \\
Others & 0 & 0 & 0.9 & 0 & 0 & 0 \\
Total & 100 & 100 & 100 & 100 & 100 & 100 \\
\hline
\end{tabular}

a: [26]. b: C12:0 Lauric acid, C 14:0 myristic acid, C 16:0 palmitic acid, C 18:0 stearic acid, C 18:1 oleic acid, C18:2 linoleic acid. HFFA-CPO: high free fatty acid crude palm oil. $\mathrm{CPO}_{\mathrm{As}}$ : crude palm oil after separation. $\mathrm{CPO}_{\mathrm{MS}}$ : Malaysian crude palm oil standard and PFAD: palm fatty acid distillate 


\section{Bahadi et al: FREE FATTY ACIDS SEPARATION FROM MALAYSIAN HIGH FREE FATTY ACID CRUDE PALM OIL USING MOLECULAR DISTILLATION}

Triacylglycerol composition (TAG) profile

The TAG composition in HFFA-CPO and $\mathrm{CPO}_{\mathrm{AS}}$ with lower free fatty acids was identified according to the equivalent carbon number $(\mathrm{ECN})$. Table 5 shows the TAGs detected for HFFA-CPO and $\mathrm{CPO}_{\mathrm{AS}}$ from the chromatograph and compared with the Malaysian crude palm oil standard. The HFFA-CPO and $\mathrm{CPO}_{\mathrm{AS}}$ are composed of at least fourteen important TAGs (Figure 2), whereas (74.2\%) in HFFA-CPO and $(84.3 \%)$ in $\mathrm{CPO}_{\mathrm{AS}}$ depending on the percentage of the MAG and DAG [27]. The dioleoyl-palmitoyl-glycerol (POO) percentage is 25 $\%$, and the percentage of dipalmitoyl-oleoyl-glycerol (POP) is $31 \%$ which are higher in $\mathrm{CPO}_{\mathrm{AS}}$. The TAGs exist in solid or liquid form depending on the nature of the fatty acids constituent. Most of the triacylglycerols are semisolid at room temperature due to an equal proportion of saturated and unsaturated fatty acids contain [19]. Table 5 shows that the results of percentage of TAGs for $\mathrm{CPO}_{\mathrm{AS}}$ are similar to the percentage of TAGs for Malaysian crude palm oil standard $\left(\mathrm{CPO}_{\mathrm{MS}}\right)$. Therefore, this separation was conducted successfully.

Table 5. Triacylglycerol composition of HFFA-CPO and $\mathrm{CPO}_{\mathrm{AS}}(\%)$

\begin{tabular}{lcccc}
\hline \multirow{2}{*}{ TAGs } & \multirow{2}{*}{ ECNs } & \multicolumn{3}{c}{ Composition (\%) } \\
\cline { 3 - 5 } & 42.0 & 0.1 & 0.2 & $0.2-0.9$ \\
\hline OLL & 42.6 & 1.5 & 1.4 & $1.3-3.4$ \\
PLL & 43.3 & 0.2 & 0.2 & $0.2-1.0$ \\
MLP & 44.1 & 0.9 & 0.9 & $1.3-2.3$ \\
OLO & 44.7 & 9.6 & 10.0 & $9.0-11.2$ \\
PLO & 45.3 & 8.2 & 8.5 & $6.5-11.0$ \\
PPL/PLP & 46.2 & 2.5 & 2.7 & $3.3-6.6$ \\
OOO & 46.8 & 20.9 & 25.0 & $20.5-26.2$ \\
POO/OPO & 47.4 & 25.0 & 31.0 & $27.1-31.0$ \\
PPO/POP & 48.0 & 2.3 & 0.5 & $0.7-7.2$ \\
PPP & 48.8 & 0.7 & 1.0 & $1.0-3.6$ \\
SOO & 49.4 & 2.2 & 2.7 & $4.6-5.9$ \\
POS & 50.0 & 0.02 & 0.1 & $0.1-1.8$ \\
PPS & 50.0 & 0.1 & 0.1 & $0.1-1.4$ \\
SOS & & 74.2 & 84.3 & $\geq 90 \%$ \\
\hline TAG \% & & 19.9 & 13.8 & $<7.7 \%$ \\
DAG \% & & 5.9 & 1.9 & $\leq 0.5 \%$ \\
MAG \% & & & CPO $_{\text {a }}$ \% &
\end{tabular}

a: [28 - 30], ECNs: equivalent carbon number. HFFA-CPO: high free fatty acid crude palm oil. $\mathrm{CPO}_{\mathrm{As}}$ : crude palm oil after separation. $\mathrm{CPO}_{\mathrm{MS}}$ : Malaysian crude palm oil standard M: myristic, P: palmitic, S: stearic, O: oleic, L: linoleic acid. 

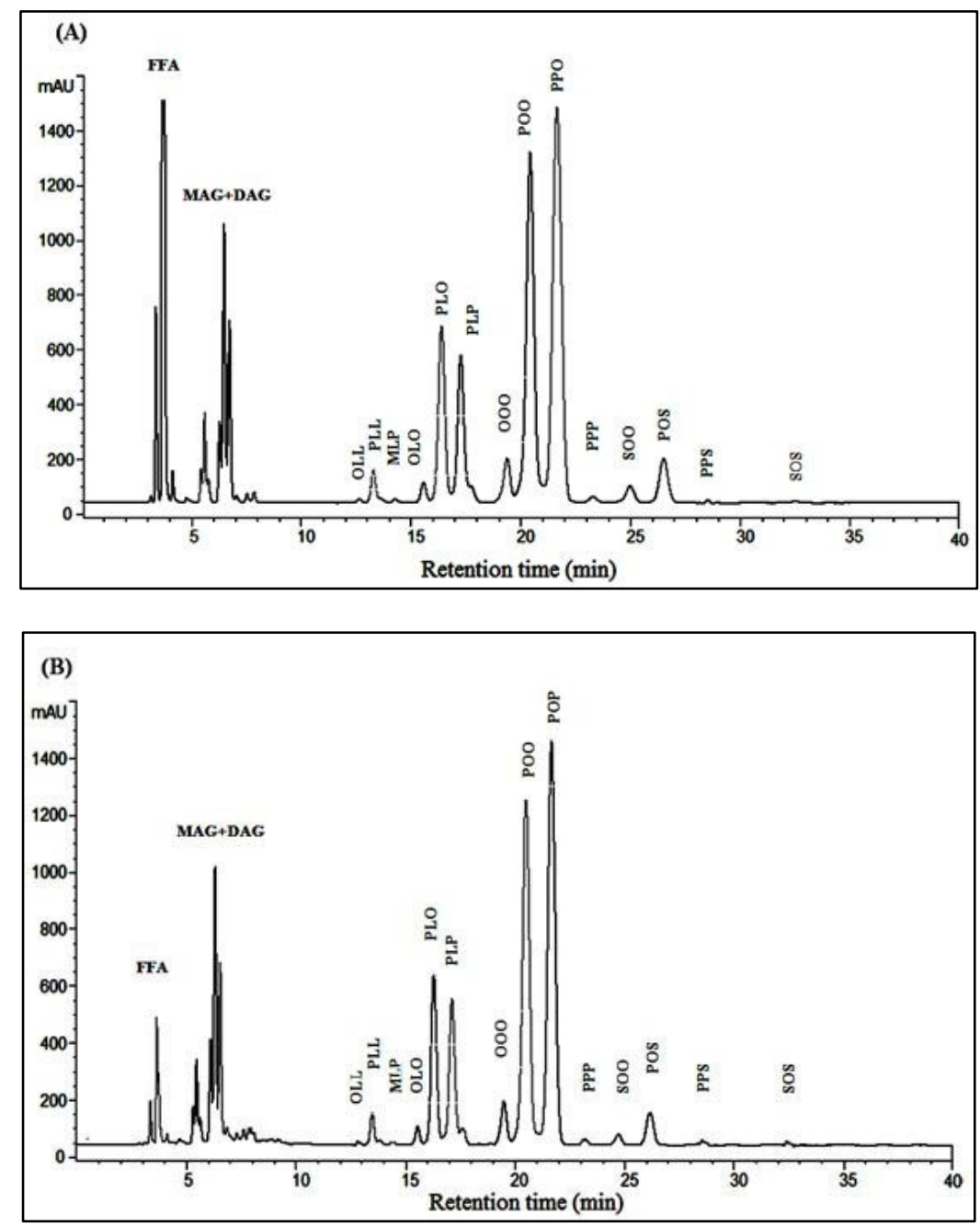

Figure 2. Triacylglycerols (TAGs) profiles chromatograms of (A) HFFA-CPO (B) $\mathrm{CPO}_{\mathrm{AS}}$

\section{Conclusion}

The high free fatty acids content in crude palm oil is unfavourable condition and need to be reduced for edible oils usage. The separation was accomplished successfully as high percentage of free fatty acids has been isolated from the crude palm oil. The optimum free fatty acid separation process conditions were at $2.3 \mathrm{~g} / \mathrm{min}$ flow rate, $350 \mathrm{rpm}$ wipers speed, $150{ }^{\circ} \mathrm{C}$ to $265^{\circ} \mathrm{C}$ evaporator temperature range, and 10 torr pressure. The yield of crude palm oil which is edible favour after the separation $\left(\mathrm{CPO}_{\mathrm{AS}}\right)$ is $88 \%(\mathrm{wt} / \mathrm{wt})$. The FFA recovered in the distillate can be utilized in future for industrial applications such as in biolubricant and bioplastic production.

\section{Acknowledgement}

We thank UKM for the project funding under university research grant no FRGS/2/2014/ST01/UKM/02/1 and Sime Darby research grant no ST-2014-019.

\section{References}

1. Poku, K. (2002). Small-scale palm oil processing in Africa. FAO Agricultural Services Bulletin, 148: 1 - 59.

2. Basiron, Y. and Weng, C. K. (2004). The oil palm and its sustainability the oil palm and its sustainability. Journal of Oil Palm Research, 16(1): 1 - 10. 
3. Nagendran, B., Unnithan, U. R., Choo, Y. M. and Sundram, K. (2000). Characteristics of red palm oil, a carotene- and vitamin E-rich refined oil for food uses. Food and Nutrition Bulletin, 21(2): 189 - 194.

4. Tarmizi, A. H. A., Siew, W. L. and Kuntom, A. (2008). Production of palm oil reference materials for the determination of solid fat content. Journal of Food Quality, 31(6): 673 - 685.

5. Prasanth Kumar, P. K. and Gopala Krishna, A. G. (2014). Physico-chemical characteristics and nutraceutical distribution of crude palm oil and its fractions. Grasasy Aceites, 65(2): 1 -12.

6. Azlan, A., Prasad, K. N., Khoo, H. E., Abdul-Aziz, N., Mohamad, A., Ismail, A. and Amom, Z. (2010). Comparison of fatty acids, vitamin $\mathrm{E}$ and physicochemical properties of Canarium odontophyllum Miq. (dabai), olive and palm oils. Journal of Food Composition and Analysis, 23(8): 772 - 776.

7. Berger, K.G., (2006). Understanding oils and fats. Global Oil Fat Business Magazine 3 (4): 50 - 53.

8. Tan, Y. A. (1994). Analytical techniques in palm oil and palm kernel oil specifications. Palm Oil Research Institute of Malaysia, 38(2.49): 45 - 77.

9. Moh, M. H., Tang, T. S., Man, Y. C. and Lai, O. M. (1999). Rapid determination of peroxide value in crude palm oil products using Fourier transforms infrared spectroscopy. Journal of Food Lipids, 6(4): 261 - 270.

10. Purseglove, J. W. (1985). Tropical crops-monocotyledons. London: Longman.

11. Cermak, S. C., Kenar, J. A. and Evangelista, R. L. (2012). Distillation of natural fatty acids and their chemical derivatives. Intech Open Access Publisher, pp. 109 - 142.

12. Shah, K. J. and Venkatesan, T. K. (1989). Aqueous isopropyl alcohol for extraction of free fatty acids from oils. Journal of the American Oil Chemists Society, 66(6): 783 - 787.

13. Supardan, M. D. and Satriana, S. (2009). Esterification of free fatty acid in crude palm oil off grade. Jurnal Rekayasa Kimia \& Lingkungan, 7(2): $70-74$.

14. Liu, D., Shi, J., Posada, L. R., Kakuda, Y. and Xue, S. J. (2008). Separating tocotrienols from palm oil by molecular distillation. Food Reviews International, 24(4): 376 - 391.

15. Martins, P. F., Ito, V. M., Batistella, C. B. and Maciel, M. R. W. (2006). Free fatty acid separation from vegetable oil deodorizer distillate using molecular distillation process . Journal from Separation and Purification Technology 48: $78-84$.

16. AOCS (1989). Official methods and recommended practices of the American Oil Chemists' Society (4th ed.). Champaign Illinois, USA

17. Salimon. J., Said. M., Ramli. S. and Lazim. M. (2006). Oil and Fat Analysis. UKM Publishing, Bangi, Malaysia.

18. PORIM Test Methods (1995). Kuala Lumpur: Palm Oil Research Institute of Malaysia (PORIM).

19. Gunstone, F. D. (2002). Vegetable oils and food technology: Composition, properties and use, pp 1-352.

20. Ichihara, K. I. and Fukubayashi, Y. (2010). Preparation of fatty acid methyl esters for gas-liquid chromatography. Journal of Lipid Research, 51(3): $635-640$.

21. Cunha, S. C., and Oliveira, M. B. P. P. (2006). Discrimination of vegetable oils by triacylglycerols evaluation of profile using HPLC/ELSD. Food Chemistry, 95(3): 518 - 524.

22. Salimon, J., Abdullah, B. M. and Salih, N. (2011). Hydrolysis optimization and characterization study of preparing fatty acids from Jatropha curcas seed oil. Chemistry Central Journal, 5(1): $67-76$.

23. Corley, R. H. V. and Tinker, P. B. (2003). The oil palm. USA: Blackwell, pp. $450-471$.

24. O'Brien, R. D. (2009). Fat and oils: formulating and processing for applications. 3rd ed. Florida, USA: CRC Press Taylor \& Francis Group.

25. Radizian, R., Sue, T. T., and OOI, C., Wong, S. K. (2009). Pocket book of palm oil uses. Malaysian Palm Oil Board, Kuala Lumpur, Malaysia.

26. Sambanthamurthi, R., Sundram, K. and Tan, Y. (2000). Chemistry and biochemistry of palm oil. Progress in lipid research, 39: $507-558$.

27. Ku, C. S. and Mun, S. P. (2008). Characterization of seed oils from fresh Bokbunja (Rubus coreanus Miq.) and wine processing waste. Bioresource technology, 99(8): 2852 - 2856.

28. Lin, S. W. (2002). 3 palm oil. Vegetable oils in food technology: Composition, properties and uses, 59.

29. Gee, P. T. (2007). Analytical characteristics of crude and refined palm oil and fractions. European Journal of Lipid Science and Technology, 109(4): 373 - 379.

30. Gibon, V., De Greyt, W. and Kellens, M. (2007). Palm oil refining. European Journal of Lipid Science and Technology, 109(4): 315 - 335 . 